\title{
Effect of Pounding on the Global Responses of Adjacent Buildings
}

\author{
Dr. A.K. Sinha ${ }^{1}$, and Saket Kumar ${ }^{2}$
}

\begin{abstract}
Pounding is very complex phenomenon. Due to pounding during strong ground motion, the acceleration at pounding level considerably increases and generates extra pounding force which causes major structural damages or sometime results into building collapse.

This paper deals with the study of effects on global response of structures and response of non-structural element due to pounding during an earthquake. Time history analysis has been done for evaluating the pounding effects for different models of building when subjected to various ground motions. The results of the study have shown the effect of pounding on global response of adjacent structures in terms of acceleration, and impact forces which get amplify in many times.
\end{abstract}

Keywords - Earthquake, Global response, Pounding, SAP 2000

\section{INTRODUCTION}

$\mathrm{E}$ XPERIENCES of past and recent earthquake-damages have well established the fact that buildings constructed very near to each other or without any gap between them, tend to collide to each other during moderate to strong ground motion [1],[2],[7]. This building collision between adjacent buildings during an earthquake is termed as pounding which commonly occurs due to their different dynamic characteristics, adjacent buildings vibrate out of phase and there is insufficient seismic gap between them. This situation can easily be seen in metropolitan cities where buildings have been constructed very near to each other due to very high cost of land and lack of knowledge about pounding and its consequences [2].

In case of pounding during strong ground motion, the acceleration at pounding level considerably increases and generates extra pounding force which causes major structural damages or sometime results into building collapse [10]. It may be possible that structural components of buildings do not get damaged severely due to pounding, during a moderate earthquake but it can damage non-structural elements or can alter their functionality which is highly undesirable in institutions like hospitals..

To avoid pounding between adjacent buildings, most of the countries in all over the world such as India, Australia, U.S.A., Canada, Egypt, Greece have adopted their own code specifications for minimum separation gap between buildings. But it is often seen that these regulations of minimum seismic

${ }^{1}$ Professor, Department of Civil Engineering, National Institute of Technology, Patna, India.

${ }^{2}$ Research scholar, Structural Engineering, National Institute of Technology, Patna, India. gap between poundings are neither followed by landowners nor strictly implemented by respective governments. This leads to a situation like Mexico City earthquake (1985) where, $40 \%$ of 330 collapses or severely damaged buildings are cause of pounding only [7].

It is well established fact that providing a proper seismic gap between adjacent building is one of the best methods to reduce the effect of pounding (Masion and Kasai et al, 1992). Seismic codes and regulations for the minimum separation gap between the adjacent buildings have been specified in worldwide to exclude seismic pounding effect.

Square root of sum of squares (SRSS) rule: $S=\sqrt{u_{A}{ }^{2}+u_{B}{ }^{2}}$

Absolute Sum (ABS) rule: $S=u_{A}+u_{B}$

Double Difference Combination (DDC) method:

$$
S=u_{R e l}=\sqrt{u_{A}^{2}+u_{B}^{2}-\rho_{A B} u_{A} u_{B}}
$$

Where $u_{A}, u_{B}$ and $u_{R e l}$ are mean peak values of, $u_{A}(t), u_{B}(t)$ and $u_{R e l}(t)$ respectively. $\rho_{A B}$, is correlation coefficient which depends upon the period ratio, $r=T_{B} / T_{A}$, as well as $\zeta_{\mathrm{A}}$ and $\zeta_{\mathrm{B}}$, and is given by

$$
\rho_{A B}=\frac{8 \sqrt{\zeta_{A} \zeta_{B}}\left(\zeta_{A}+r \zeta_{B}\right) \cdot r^{1.5}}{\left(1-r^{2}\right)^{2}+4 r \zeta_{A} \zeta_{B}\left(1+r^{2}\right)+4\left(\zeta_{A}{ }^{2}+\zeta_{B}{ }^{2}\right) r^{2}}
$$

Where, $T_{A}, \zeta_{A}$ and $T_{B}, \zeta_{B}$ are natural periods and damping ratio of systems $A$ and $B$, respectively.

Non-linear dynamic analysis: Non-linear dynamic analysis has been carried out considering various earthquake ground motion of different PGA. The equation of motion for the structure when it subjected to ground motion is given as:

$$
[M]\left\{\ddot{X}_{b}\right\}+[C]\{\dot{X}\}+[K]\{X\}=-[M][I]\left\{\ddot{X}_{g}\right\}
$$

Where, $[M]$ is mass matrix, $[C]$ is damping matrix and $[K]$ is stiffness matrix of the building. $\{X\}$ and $\left\{X_{b}\right\}$ are displacements of superstructure and base of the building. $\left\{\ddot{X}_{b}\right\}$ and $\left\{\ddot{X}_{g}\right\}$ are base acceleration and acceleration relative to ground. $[I]$ is the earthquake influence coefficient matrix.

Further, all non-linear properties are restricted to the nonlinear link element i.e., gap element, only. The above nonlinear dynamic equation considering the superstructure as elastic and link as non-linear can be written as:

Where,

$$
\begin{gathered}
{[M]\{\ddot{X}(t)\}+[C]\{\dot{X}(t)\}+\left[K_{L}\right]\{X(t)\}+r_{N}(t)} \\
=r(t)-\left[r_{N}(t)-K_{N} X(t)\right]
\end{gathered}
$$

$$
[K]=\left[K_{L}\right]+\left[K_{N}\right]
$$

$[M]$ is diagonal mass matrix; $[C]$ is the proportional damping matrix; $\left[K_{L}\right]$ is stiffness matrix of all linear elements; $\left[K_{N}\right]$ is 
stiffness matrix for all of the non-linear degrees of freedom; $r_{N}$ stands for the vector of forces from non-linear degrees of freedom in the gap elements; $r(\mathrm{t})$ in the equation is vector of applied load; $\{\ddot{X}(t)\},\{\dot{X}(t)\}$ and $\{X(t)\}$ are the relative acceleration, velocity and displacement with respect to ground, respectively. The effective stiffness at non-linear degrees of freedom is arbitrary, but the value of it varies between zero and the maximum stiffness of that degree of freedom.

Gap element: Gap element is a link element defined in SAP 2000. It is compression only member and is used to model the collision between buildings and simulating the effect of pounding

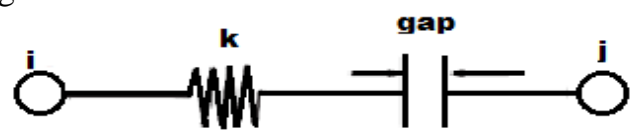

Fig. 1: Gap element model from SAP 2000

The force deformation relationship of gap element is given below.

$$
f=\left\{\begin{array}{cl}
k(d+g a p), & \text { if }(d+g a p)<0 \\
0, & \text { otherwise }
\end{array}\right.
$$

Where, $k$ is spring constant, 'gap' is the initial opening which must be positive or zero and $d$ is the relative displacement across the spring. Generally stiffness of gap element $(\mathrm{k})$ is recommended as one or two orders of magnitude greater than equivalent adjacent springs. Here it is taken $4.776 \times 10^{5} \mathrm{kN} / \mathrm{m}$.

\section{Methodology Of The Study}

The study has been carried out by assuming three different cases viz. (i) buildings of different heights but same floor levels (ii) buildings of different heights but different floor levels (iii) buildings in a series having different height and different physical characteristics. Non-linear dynamic analysis has been done by using response spectra method and time history analysis. Response envelopes of adjacent buildings are provided in terms of acceleration of floor. The impact forces achieved by incorporation of gap elements are also shown in form of response envelop for different ground motions.

The six types of ground accelerations such as Petrolia(1992), Northridge(1994), El Centro(1940), Loma Prieta(1989), Holliste, Array 06 have been applied to models of different cases to find response of the models and to plot response envelope for acceleration, of models. The peak ground acceleration (PGA) of these ground motions varies from $0.22 \mathrm{~g}$ to $0.883 \mathrm{~g}$.

\section{Modelling Of The Structures}

Adjacent buildings are modeled in SAP2000v17 and gap elements are introduced between buildings to analyse the effect of pounding between them.

In $1^{\text {st }}$ two cases building of 7 stories (say building A) and building of 5 stories (say building B) are considered. Live load of $3 \mathrm{kN} / \mathrm{m}^{2}$ and $2.5 \mathrm{kN} / \mathrm{m}^{2}$ has been used for building $\mathrm{A}$ and building $\mathrm{B}$ respectively.

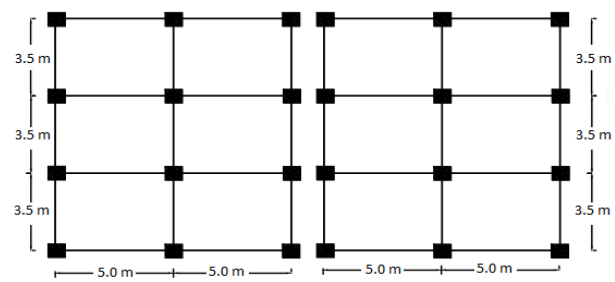

(a)

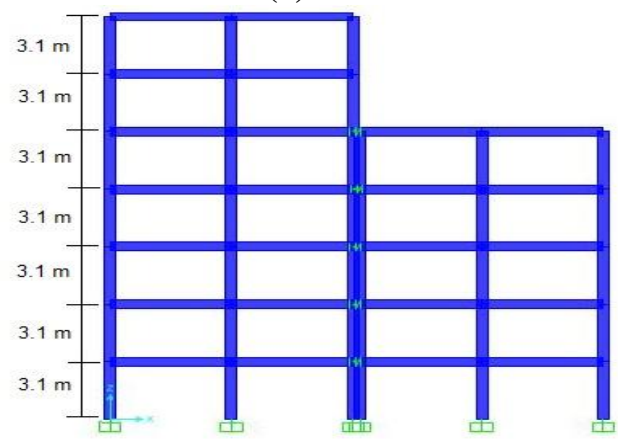

(b)

Fig.2 :(a) Plan view and (b) Elevation view of adjacent buildings modeled in case I

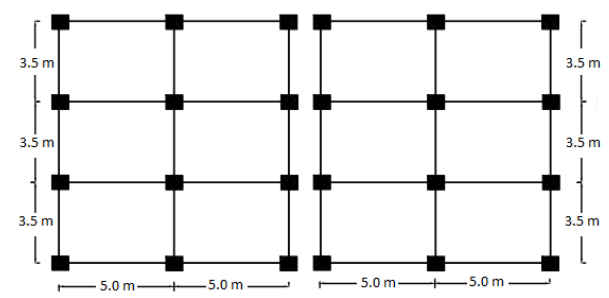

(a)

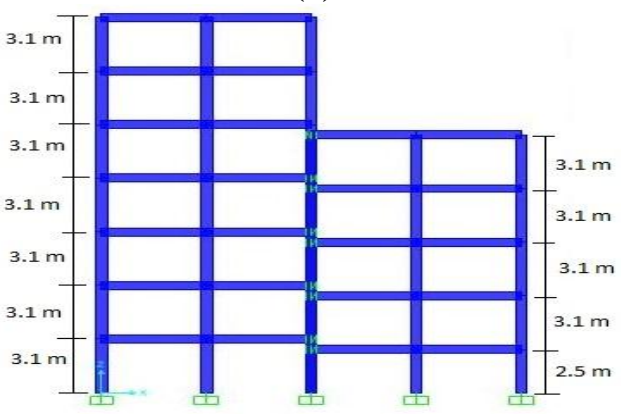

(b)

Fig.3 :(a) Plan view and (b) Elevation view of adjacent buildings modeled in case II

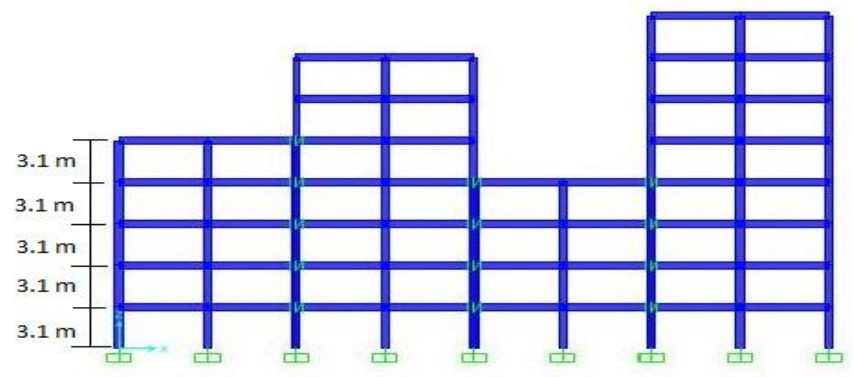

Fig 4: Elevation of buildings modeled in case III

\section{NUMERICAL STUDIES}

Global response of buildings after pounding is given below in terms of acceleration for different cases when buildings subjected to different ground motions. 


\section{A. Buildings of different height but same floor level}

For this case study, models of 7 storey building (say building A) and 5 storey building (say building B) have been considered

\section{BUILDING A}

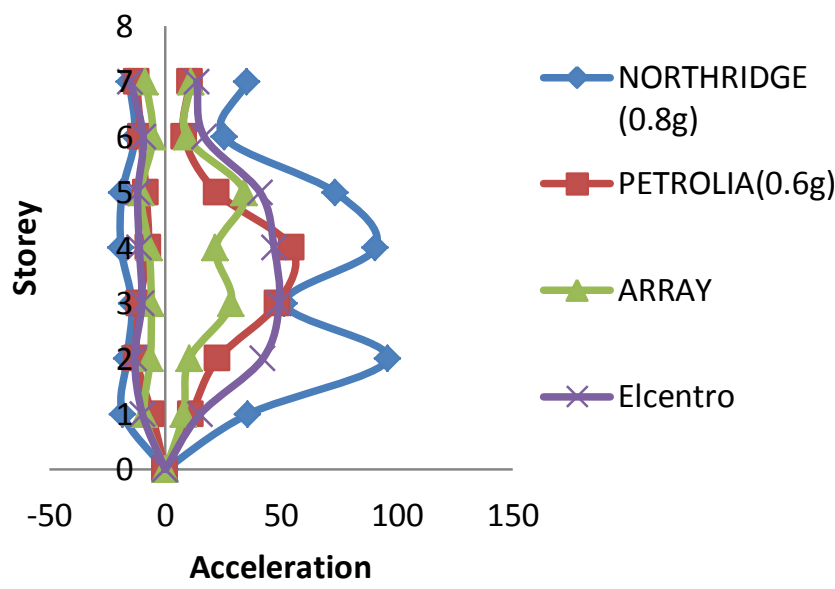

Fig 5: Response envelope of building A in terms of acceleration (case $A$ )

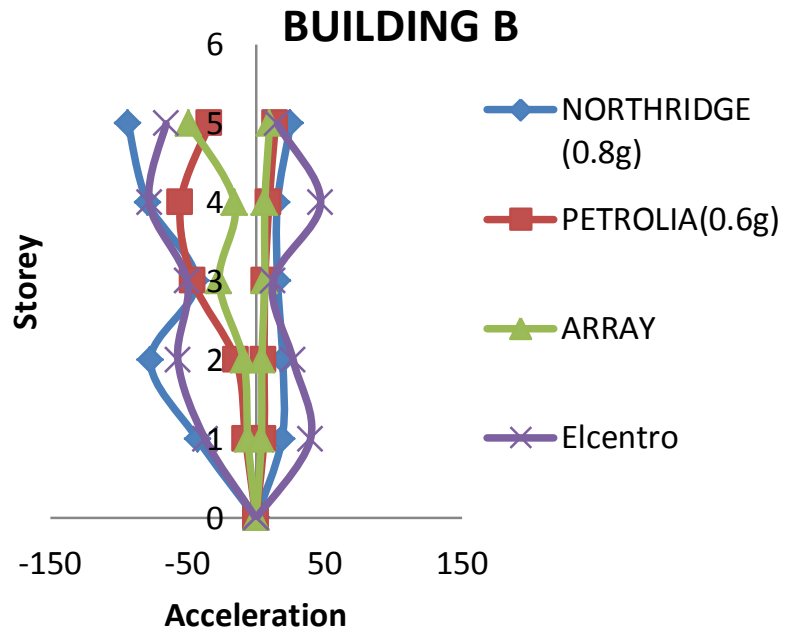

Fig 6: Response envelope of building $\mathrm{B}$ in terms of acceleration (case $A$ )

It is observed in fig. 5 and 6 that response envelopes due to Northridge ground motion (PGA 0.883g, $\mathrm{M}<7$ ) and Array (or Parkfield) ground motion (PGA $0.434 \mathrm{~g}, \mathrm{M}<7$ ) are similar. These curves are zigzag in pattern and sharp troughs are also observed at $3^{\text {rd }}$ and $4^{\text {th }}$ floor. Further, response envelopes due to Petrolia ground motion (PGA0.662g, M>7) and El Centro ground motion (PGA0.348g, M>7) are similar and smooth throughout the height of building. It also observed that the acceleration is increasing up to $4^{\text {th }}$ floor and then decreasing gradually which is expected too.

For building B, response envelopes due to Northridge ground motion (PGA 0.883g, M<7) and Array (or Parkfield) ground motion (PGA $0.434 \mathrm{~g}, \mathrm{M}<7$ ) are similar in pattern i.e. zigzag. Maximum accelerations are observed at roof top of the building due to Northridge and Array ground motions.
Further, max accelerations due to Petrolia and El Centro ground motions are observed at $4^{\text {th }}$ floor of the building.

\section{Impact Force (link A-B)}

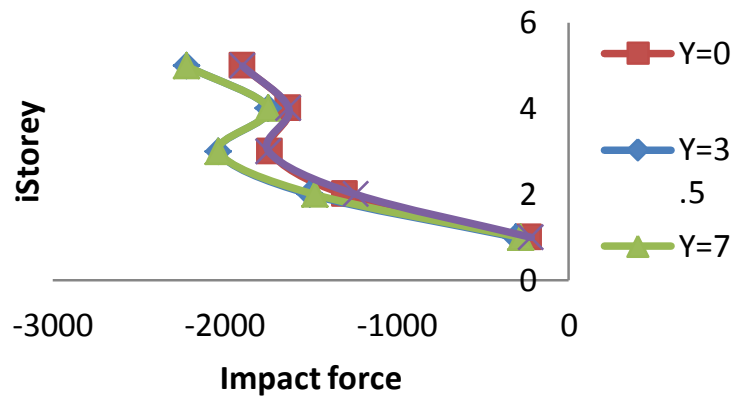

Fig 7: Response envelope of impact force of collisions between buildings during pounding for El Centro ground motion.

Impact forces have been evaluated using gap elements, linking between adjacent buildings. These are maximum at roof top of the building B i.e., building of lower height. Difference between the impact forces at $1^{\text {st }}$ floor and $2^{\text {nd }}$ floor is very high. Impact forces at $\mathrm{Y}=3.5$ and $\mathrm{Y}=7$ are higher than impact forces at $\mathrm{Y}=0$ and $\mathrm{Y}=11.5$ plane of building throughout the whole length of the building $\mathrm{B}$.

\section{B. Adjacent buildings of different heights and different floor levels}

For this case, models of 7 storey building (say building A) and 5 storey building (say building B) have been considered. The floor levels of both buildings have been kept at different level. The elevation view of the models is shown in fig 3 .

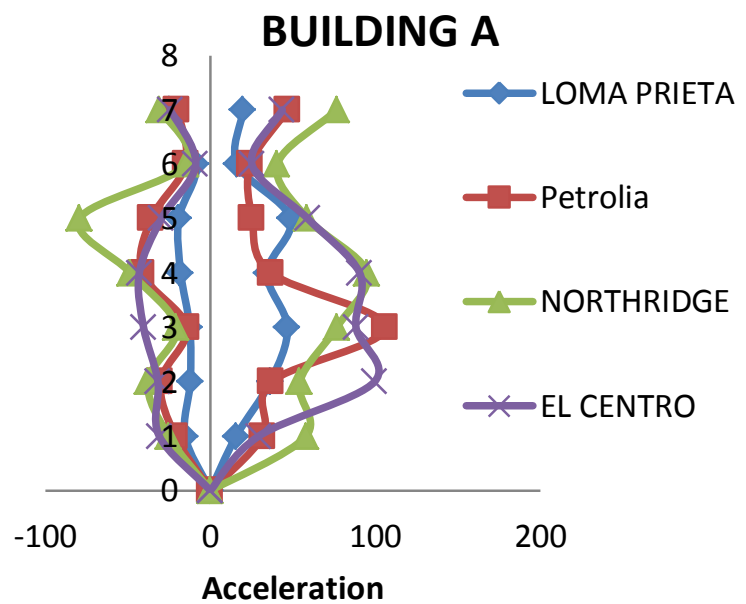

Fig 8: Response envelope of building $\mathrm{A}$ in terms of acceleration (case $B$ ) 


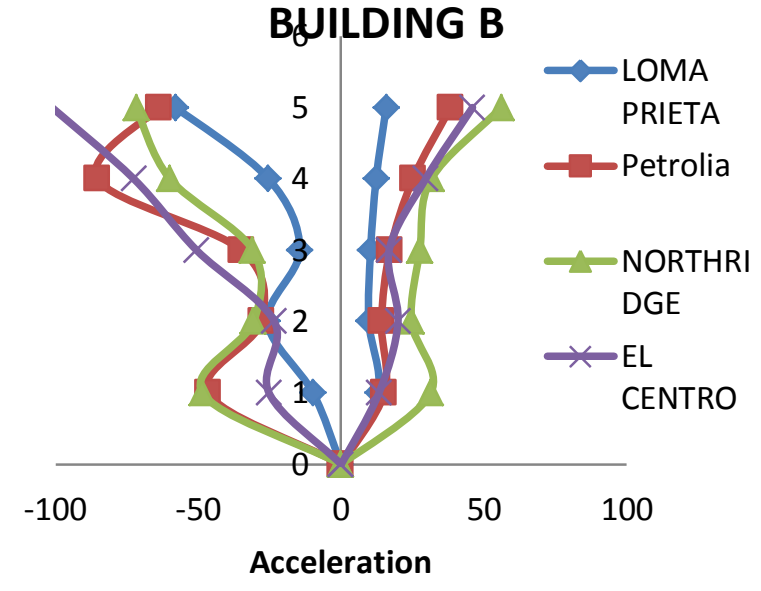

Fig 9: Response envelope of building B in terms of acceleration (case $B$ )

For building A, in fig 8 and 9, response envelopes of zigzag pattern are observed at pounding side as well as non-pounding side of the building. Although, response envelopes of pounding side of the building are of higher values than response envelopes of non-pounding side as expected. Response envelopes due to Petrolia ground motion and Northridge ground motions are relatively smoother than response envelopes due to Loma Prieta ground motion and El Centro ground motion. Maximum accelerations due to different ground motions are observed, located at $3^{\text {rd }}$ or $4^{\text {th }}$ floor level and their values are precise to each other except of Loma Prieta ground motion.

For building B, response envelopes of zigzag pattern are observed but only at pounding side of the building. Response envelopes due to Petrolia (PGA 0.662g) and Northridge (PGA $0.883 \mathrm{~g}$ ) ground motions are similar. Maximum values of response envelopes are located at roof top of the building for Loma Prieta, Northridge and El Centro ground motions. Maximum value of response envelope due to Petrolia is located at $4^{\text {th }}$ floor of the building.

C. Buildings in a series of different heights and different physical characteristics

This is case type $C$ and for this case, models of 5 storey building (say building A) and 7 storey building (say building B), 4 storey building (say building C), 8 storey building (say building D) have been considered. The floor levels of every building in the series have been kept at same level. The elevation view of building model has shown in fig. 4.

For building A, in fig 13, it is observed that response envelopes due to Petrolia (PGA 0.662g) and Northridge (PGA $0.883 \mathrm{~g}$ ) ground motions are of similar patterns and response envelopes due to Hollister (PGA $0.376 \mathrm{~g}$ ) and El Centro (PGA $0.348 \mathrm{~g}$ ) have same patterns. Maximum value of every response envelopes located at roof top of the building i.e., $5^{\text {th }}$ floor level of building B.

Building B is sandwiched between building A (5 storey) and building $\mathrm{C}$ (4 storey) and pounding is expected from both side of the building. It is also observed that response envelopes of building $\mathrm{B}$ towards building $\mathrm{A}$ side have maximum value at $4^{\text {th }}$ floor level of the building while response envelopes towards building $\mathrm{C}$ side have maximum values mostly located at $2^{\text {nd }}$ and $3^{\text {rd }}$ floor level. It is also observed that after attaining a maximum values, response envelopes are declining with height of building and are converged at the roof top of the building.

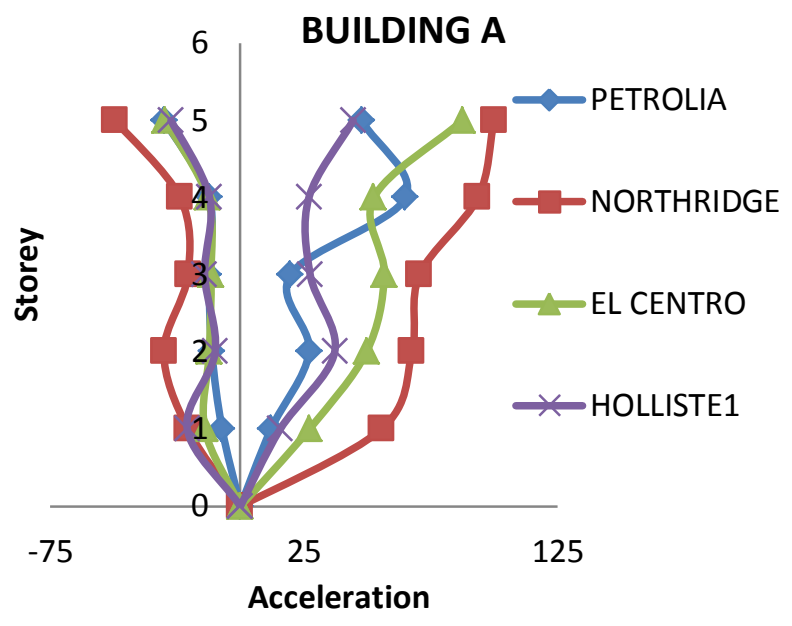

Fig 10: Response envelope of building A in terms of acceleration (case $C$ )

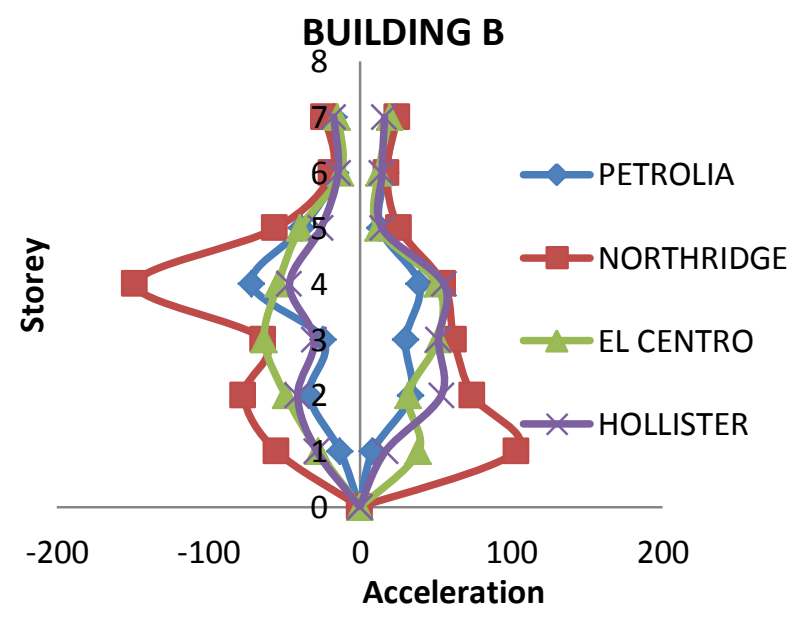

Fig 11: Response envelope of building B in terms of acceleration (case $C$ )

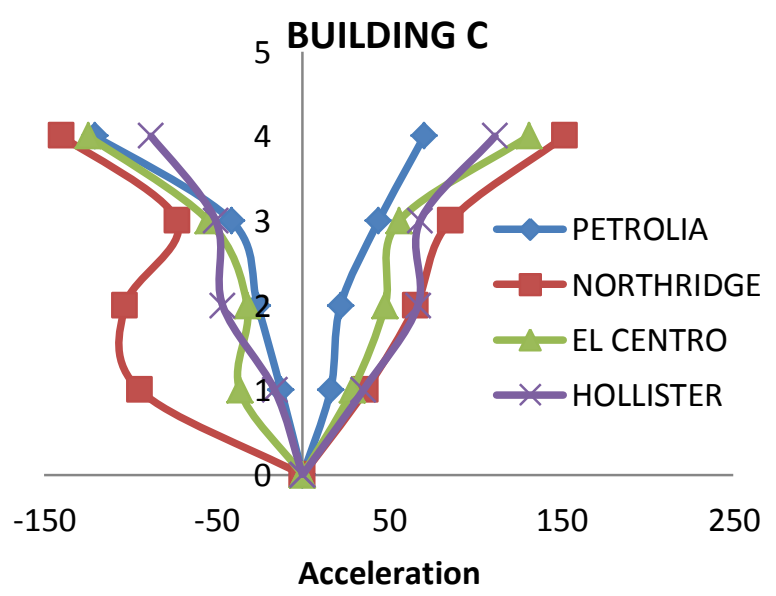

Fig 12: Response envelope of building $\mathrm{C}$ in terms of acceleration (case $C$ ) 


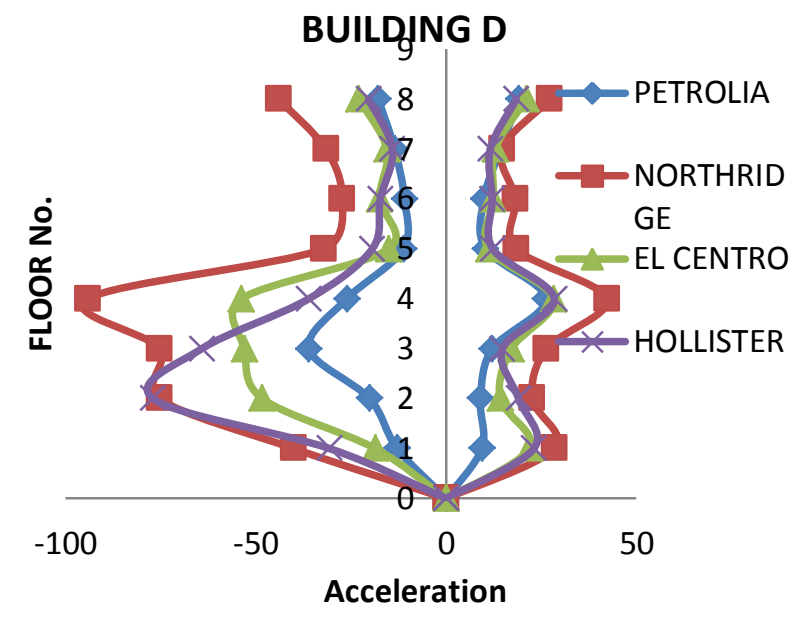

Fig 13: Response envelope of building D in terms of acceleration (case $C$ )

Building C (4 storey) is sandwiched between building B (7 storey) and building D (8 storey) and pounding is expected from both side of the building. Response envelopes due to every ground motions are maximised at roof top of the building.

Building D (8 storey) is last building of the series. Maximum values of acceleration of response envelopes are located at $3^{\text {rd }}$ and $4^{\text {th }}$ floor. After attaining a maximum value, response envelopes are declining with height of building and are converged at the roof top of the building. It is also observed that response envelopes of non-pounding side of building have crests at $1^{\text {st }}$ floor level and $4^{\text {th }}$ floor level.

\section{RESULTS}

TABLE I

COMPARISON OF MAXIMUM ACCELERATIONS BETWEEN TWO DIFFERENT CASES FOR BUILDING OF HIGHER HEIGHT (I.E., BUILDING A)

\begin{tabular}{|c|c|c|c|}
\hline Cases (building & \multicolumn{3}{|c|}{ Maximum acceleration $\left(\mathrm{m} / \mathrm{s}^{2}\right)$} \\
\cline { 2 - 4 } position) & Northridge & Petrolia & El Centro \\
\hline $\begin{array}{c}\text { Adjacent buildings at } \\
\text { different height but } \\
\text { same floor level }\end{array}$ & 90.699 & 54.706 & 49.165 \\
\hline $\begin{array}{c}\text { Adjacent buildings at } \\
\text { different height and } \\
\text { different floor level }\end{array}$ & 95.00 & 106.316 & 90.505 \\
\hline
\end{tabular}

TABLE II

COMPARISON OF MAXIMUM ACCELERATIONS BETWEEN TWO DIFFERENT CASES FOR BUILDING OF LOWER HEIGHT (I.E., BUILDING B)

\begin{tabular}{|c|c|c|c|}
\hline Cases (building & \multicolumn{3}{|c|}{ Maximum acceleration $\left(\mathrm{m} / \mathrm{s}^{2}\right)$} \\
\cline { 2 - 4 } position) & Northridge & Petrolia & El Centro \\
\hline $\begin{array}{c}\text { Adjacent } \\
\text { buildings at } \\
\text { different height } \\
\text { but same floor } \\
\text { level }\end{array}$ & 93.00 & 54.98 & 77 \\
\hline $\begin{array}{c}\text { Adjacent } \\
\text { buildings at } \\
\text { different height } \\
\text { and different } \\
\text { floor level }\end{array}$ & 71.656 & 85.336 & \\
\hline
\end{tabular}

TABLE III

COMPARISON OF IMPACT FORCES BETWEEN ADJACENT SERIES OF STRUCTURES IN A ROW WITH DIFFERENT HEIGHTS

\begin{tabular}{|c|c|c|c|}
\hline \multirow{2}{*}{ Link elements } & \multicolumn{3}{|c|}{ Impact Force (kN) } \\
\cline { 2 - 4 } & Link A-B & Link B-C & Link C-D \\
\hline Ground Motion & & & \\
\hline Northridge & 2788.52 & 2228.87 & 3205.85 \\
\hline Petrolia & 1618.4 & 1461.14 & 1926 \\
\hline El Centro & 1602.66 & 1507 & 1868 \\
\hline
\end{tabular}

\section{CONCLUSION}

Global responses of adjacent structures in terms of acceleration, velocity and displacement, amplify in case of pounding between them when they subjected to strong ground motion than in no-pounding case.

It is observed that impact forces at pounding level between buildings with different height and different floor level is higher than those in case of building with different height but same floor level. It also postulates that pounding in case for building with different height and different floor level is worse than that of buildings of same level.

It is observed that floor acceleration of building in case of pounding is much higher than of no-pounding case. Further it is also observed that floor accelerations vary with height of building. Again it is also illustrated that inelastic forces of non-structural element for pounding case is much higher than those of in no-pounding case.

In case of series of buildings in a row outermost buildings suffer more damages due to pounding than inner buildings .

\section{REFERENCES}

[1] Anagnostopoulos, S. A., Spilliopoulos, K V (1992), "An Investigation of earthquake induced ponding between adjacent buildings", earthquake Engineering \& Structural Dynamics. Vol.21, No.4, and Pp.289-302.

[2] Anagnostopoulos, S. A.,(1996), "Building Pounding Re-examined : How Serious A problem is it?" Paper No. 2108, Eleventh World Conference on Earthquake Engineering, 1996.

[3] Arash Rezavani and A. S. Moghadam (2004), “ Using Shaking Table to Study Different Methods of Reducing Effects of Building Pounding During Earthquake", $13^{\text {th }}$ World Conference on earthquake Engineering , paper No. 698, Canada.

[4] Bipin Shreshta (2013), "Effects of Separation Distance and Nonlinearity on Pounding Response of Adjacent Structures", International Journal of Civil and Structural Engineering, Volume 3, No. 3.

[5] Chetan J. Chitte, Anand S. Jadhav, Hemraj R. Kumavat (2014), "Seismic Pounding Between Adjacent Building", IJRET; eISSN:231911631.

[6] Chenna Rajaram, Pradeep Kumar Ramancharla (2012), "Comparison of Codal Provisions on Pounding between Adjacent Buildings ", International Journal of Earth Sciences and Engineering, February 2012 P.P. 72-82.

[7] Gregory L. Cole, Rajesh P. Dhakal and Fred M. Turner, " Building Pounding Damage Observed in the 2011 Christchurch earthquake", NZSEE Conference, 2010.

[8] IS 4326: 1993, "Indian Standard Code of Practice for Earthquake Resistant Design and Construction of Buildings", New Delhi.

[9] IS 1893(part I): 2002, “ Indian Standard Criteria for Earthquake Resistant Design of Structures", part I General provisions and buildings, New Delhi. 
[10] K. Kasai, V.Jeng, P. C. Patel and J.A. Munshi (1992), "Seismic Pounding Effects - Survey and Analysis", ISBN 9054100605, Earthquake Engineering, $10^{\text {th }}$ World Conference, Balkerna, Rosterdam, 1992.

[11] R. C. Barros and S.M. Khatami (2012), “ Building Pounding forces for Different Link Element Models" Paper 286, $11^{\text {th }}$ International Conference on Computational Structures Technology, Scotland, 2012. 